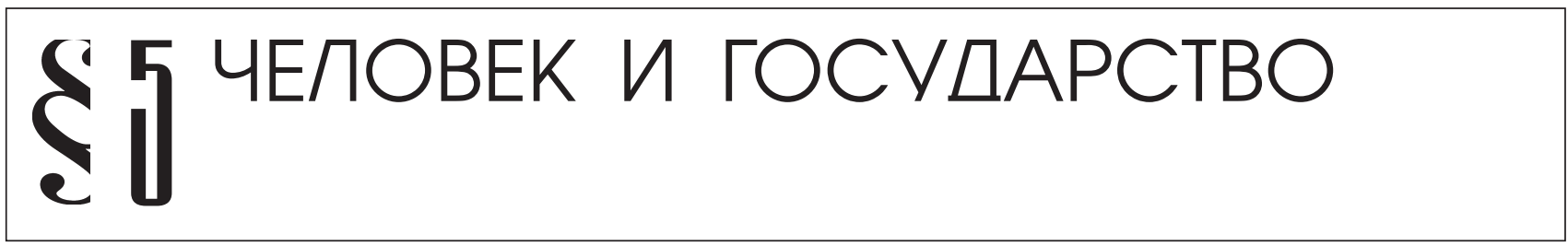

Кравец И.А.

\title{
ОГРАНИЧЕНИЯ СУДЕБНОГО ГАРАНТИРОВАНИЯ КОНСТИТУЦИИ И ПРАВО НА КОНСТИТУЦИОННО-ПРАВОВУЮ ЗАЩИТУ ОСНОВНЫХ ПРАВ И СВОБОД В РОССИЙСКОЙ ФЕДЕРАЦИИ
}

Аннотация: В статье рассматриваются правовая природа верховенства конституции, теоретические основь и способы обеспечения верховенства конституции (судебное и политическое гарантирование конституции) в доктрине и практике современного конституциионализма, некоторые ограничения судебного гарантирования конституц̧ии в контексте концептуальных основ современного конституционализма, изменение условий реализации права на конституцฺионно-правовую защиту основных прав и свобод, предложения по совершенствованию правового обеспечения и повышения эффективности конституционного судопроизводства. Раскрываются взаимосвязи между способами обеспечения верховенства конституциии и эффективностью реализации конституционных норм, особенности правовой природы российского конституционализма на современном этапе развития В статье используются методы сравнительного и системного анализа, конституционного проектирования и критического осмысления эффективности действия способов обеспечения верховенства конституции В статье рассматриваются идейные истоки современных способов гарантирования конституции и их конституционное закрепление и соотношение в доктрине и практике современного российского конституционализма и конституцчионного правосудия. Выявлены пробелы и недостатки действуюшего законодательства в сфере гарантирования конституционных норм, сформулированы предложения по совериенствованию конституционного законодательства и законодательства о конституцчионном правосудии.

Abstract: The article concerns legal nature of the supremacy of the Constitution, as well as theoretical bases and means for the guarantees of such supremacy, both judicial and political, in the doctrine and practice of the modern constitutionalism, and some limitations to the constitutional guarantees within the context of conceptual bases of modern constitutionalism, changes in the conditions for the implementation of the right to constitutional legal protection of basic rights and freedoms, as well as some propositions on the improvement of legal guarantees and raising efficiency in the sphere of constitutional judicial procedure. The author discusses the relations between the various means used in order to guarantee supremacy of the constitution and the efficient implementation of constitutional norms, as well as specific features of the modern Russian constitutionalism at the current stage of its development. The article uses the methods of comparative and systemic analysis, constitutional projections and critical evaluation of efficiency of such methods. The article also includes analysis of ideological sources of the modern guarantees of the Constitution and their constitutional enshrinement and correlation in the doctrine and practice of the modern Russian constitutionalism and constitutional justice. The author uncovers gaps and shortcomings in the current legislation in the sphere of guarantees of constitutional norms, and formulates the provisions for the improvement of constitutional legislation and legislation on constitutional justice.

Ключевые слова: судебное гарантирование конституциии, верховенство конституции, конституционализм, политический гарант конституцчии, конституцчионно-правовая защчита, конституционное правосудие, жалоба граждан, провозглашение постановлений, конституционно-правовые инновации, срок провозглашения Keywords: judicial guarantees of the Constitution, supremacy of the Constitution, constitutionalism, political guarantor of the constitution, constitutional legal protection, constitutional justice, complaints of citizens, proclamation of judgments, constitutional legal innovation, period for proclamation. 
DOI: $10.7256 / 1811-9018.2013 .13 .10424$

При цитировании этой статьи сноска на dоі обязательна

\section{Право и политика $13(168) \cdot 2013$}

\section{Судебное гарантирование конституции как судебный конституционализм и его ограничения}

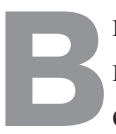
исторической ретроспективе отмечается существование античного, средневекового и современного конституционализма. Многие компоненты современного конституционализма основываются на доктрине и практике верховенства конституции. Данного принципа конституционализма (или юридического свойства конституции) не было как в античных правовых системах, так и в период средних веков. Создание концепта верховенства конституции связано с периодом конца XVIII века, значительный импульс развитию концепта верховенства конституции в XX столетии придал появившейся институт конституционного правосудия.

Формирование российского конституционализма как правового явления немыслимо без надлежащего обеспечения и проведения в жизнь принципа верховенства конституции. Следует согласиться с лаконичной формулировкой Ю. Лимбах о том, что «концепт верховенства конституции присуждает высшую власть в правовой системе конституции» ${ }^{1}$. На пути к реализации этого принципа России удалось преодолеть пока только частично ключевые трудности и проблемы.

Конституции присущи аксиологические свойства. Аксиологизм конституции - ценностные основания современного конституционализма. По мнению Н.С. Бондаря, именно аксиологическими свойствами определяется уникальность Конституции с точки зрения ее юридических, политико-идеологических, философско-мировоззренческих и иных характеристик. Ценностная значимость присуща как Конституции в целом (с точки зрения, прежде всего, таких ее юридических характеристик, как верховенство, высшая юридическая сила, прямое действие, сочетание стабильности и динамизма и т.п.), так и конкретным ее нормам, которые являются в этом случае отражением фактически сложившихся и юридически признаваемых представлений о социальных приоритетах и наиболее оптимальных моделях обустройства общественной и государственной жизни, о соотношении ценностей власти и свободы, равенства и справедливости, рыночной экономики и социальной государственности и т.д. ${ }^{2}$

\footnotetext{
${ }^{1}$ Limbach Jutta. The Concept of the Supremacy of the Constitution // The Modern Law Review.- 2001.- Vol.64.- No 1.- P.1.

${ }^{2}$ Бондарь Н.С. Буква и дух российской Конституции: 20-летний опыт гармонизации в свете конституционного правосудия // Журнал российского права. 2013. № 11. С. 5 - 17.
}

Для обоснования обеспечения верховенства конституции могут применяться две концепции гарантирования конституции: 1) концепции судебного гарантирования конституции, когда ее гарантом провозглашается специализированный орган конституционного контроля - Конституционный Суд или суд общей юрисдикции; 2) концепция политического гарантирования конституции, когда ее гарантом провозглашается глава государства, обеспечивающий реализацию конституционных норм и определяющий основные направления законодательной политики и деятельности правительства.

Концепция судебного гарантирования конституции опирается на идеи Ганса Кельзена о судебной гарантии конституции и конституционной юстиции ${ }^{3}$, которые получили оформление в кельзеновскую модель конституционного контроля, послужившую теоретической основой для европейских систем конституционного правосудия, в том числе для создания российской модели Конституционного Суда РФ.

Концепция политического гарантирования конституции главой государства восходит к идеям Карла Шмитта, разрабатывавшего теорию политической теологии и связывавшего функцию гаранта конституции с политическим сувереном (политическим богом), каким считал главу современного государства. В работе 1931 года «Гарант конституции», посвященной поиску выхода из системного конституционного кризиса Веймарской республики, К. Шмитт призывает заменить плюралистическое государство конкурирующих партий субстанциальным порядком с единой государственной волей, для чего необходима президентская диктатура в качестве гаранта конституции ${ }^{4}$.

Обе концепции гарантирования конституции находят отражение в Конституции РФ 1993 года, которая закрепляет Президента РФ в качестве гаранта конституции, прав и свобод человека и гражданина (ч.2 ст.80), и устанавливает в ст.125 полномочия Конституционного Суда РФ в сфере судебного конституционного контроля и толкования конституции.

Современный российский конституционализм, следовательно, основывается на сочетании (соотношении и взаимном влиянии) доктрины и практики политического гарантирования конституции главой государства и судебного гарантирования конституции (органом конституционного правосудия). В исследо-

\footnotetext{
${ }^{3}$ Кельзен Г. Судебная гарантия конституции (конституционная юстиция) // Право и политика. 2006. № 8, 9.

${ }^{4}$ Шмитт Карл. Государство. Право и политика. М., 2013.
} 
DOI: $10.7256 / 1811-9018.2013 .13 .10424$

При цитировании этой статьи сноска на dоі обязательна

Человек и государство

ваниях получает развитие как концепция судебного конституционализма (современная версия судебного гарантирования конституции), так и концепция политического гарантирования конституции Президентом РФ. Доктрина судебного конституционализма развивается в работах современных исследователей, судей Конституционного Суда РФ 5 .

В современном мире используются различные модели судебного гарантирования Конституции наряду с внесудебными способами защиты и правовой охраной конституции. Модели судебного гарантирования конституции как правило отражают сложившиеся и поддерживаемые государством системы конституционного контроля и конституционного правосудия. Модели судебного гарантирования конституции (американская, европейская и смешанная) опираются на особенности правовой и судебной системы, существующие в государстве, особенности государственного режима могут влиять на эффективность работы судебного гаранта Конституции.

Ограничения судебного гарантирования конституции, как правило, имеют объективный характер и вызваны особенностями правовой и судебной системы, государственной политикой в судебной сфере, исполнения (или реализации) решений органов конституционного правосудия, однако, такие ограничения могут быть связаны с принятыми и реализуемыми способами и методами толкования конституционных норм, доктриной самоограничения и профессиональными установками судей при решении вопроса о допустимости обращений или степени влияния конституционного правосудия на иные компоненты правовой и судебной системы страны.

В данной статье обсуждается несколько видов ограничений судебного гарантирования конституции применительно к опыту Российской Федерации в контексте мирового конституционного процесса.

1) Ограничения, связанные с существованием в России двух гарантов Конституции - судебного гаранта в лице Конституционного Суда РФ и политического гаранта в лице Президента РФ. Формирование доктрины и практики судебного верховенства Конституции необходимо согласовывать с конституционной поли-

\footnotetext{
${ }_{5}^{5}$ Бондарь Н.С. Судебный конституционализм в России в свете конституционного правосудия. М.: Норма; ИНФРА-М, 2011; Кравец И.А. О понятии судебного конституционализма // Правовые проблемы укрепления российской государственности: Сб. ст. / Под ред. М.М. Журавлева, А.М. Барнашова, В.М. Зуева. Томск: Издво Том. Ун-та, 2010. Ч. 46. С. 58 - 59; Ярошенко Н.И. Судебный конституционализм в Российской Федерации: понятие и система оснований // Российская юстиция. 2013. N 8. С. 4 - 6.
}

тикой Главы Российского государства. Конституционный статус судебного гаранта Конституции позволяет в России формировать доктрину и практику судебного верховенства конституции и рассматривать Конституционный Суд РФ в качестве окончательного арбитра в вопросах судебного гарантирования Конституции. Конституционный Суд РФ уполномочен в соответствии со ст.125 Конституции РФ и ст.3 ФКЗ о КС проверять конституционность федеральных конституционных законов и федеральных законов независимо от того, какой орган или должностное лицо были инициаторами таких актов. Однако насколько будет осторожен Суд, когда встанет вопрос о проверке конституционности федерального конституционного закона или федерального закона, инициированного Президентом РФ и принятого Федеральным Собранием? Представляется, что для согласования авторитетов двух гарантов Конституции и в целях предупреждения умаления престижа президентской власти, можно было бы предусмотреть предварительный конституционный контроль проектов федеральных конституционных законов и федеральных законов, инициированных Президентом РФ. Такой контроль мог бы осуществлять Конституционный Суд РФ на стадии их прохождения через палаты Федерального Собрания. Такая процедура не препятствует осуществлять предварительный парламентский контроль проектов федеральных конституционных и федеральных законов.

2) Ограничения, связанные с юридическими возможностями, предусмотренными Конституцией РФ, но не используемыми Конституционным Судом РФ. Ограничивает судебное гарантирование конституции отсутствие в течение 20 лет посланий Конституционного Суда РФ палатам Федерального Собрания. Не обеспечивается реализация нормы Конституции РФ о посланиях Конституционного Суда РФ, и не гарантируется (двумя гарантами Конституции) мониторинг состояния конституционной законности с опубликованием и общественным обсуждением (ежегодно по аналогии с посланиями Президента РФ или с иной периодичностью). Исследование методологических вопросов проблемы посланий Конституционного Суда РФ, его возможной структуры предпринято в научной литератуpe $^{6}$. Среди исследователей - судьи Конституционного

\footnotetext{
${ }^{6}$ Митюков М.A. Методология исследования проблемы послания Конституционного Суда Российской Федерации // Конституционное и муниципальное право. 2010. № 12. С. 27 - 33; Несмеянова С.Э. О возможном влиянии Конституционного Суда Российской Федерации на законодателя // Журнал конституционного правосудия. 2010. № 3. С. 6 - 9 .
} 
DOI: $10.7256 / 1811-9018.2013 .13 .10424$

При цитировании этой статьи сноска на dоі обязательна

\section{Право и политика $13(168) \cdot 2013$}

Суда РФ, предлагающие рассматривать Послания как одно из средств овеществления государственной политики. В этом случае послания, по мнению А.Н. Кокотова, имели бы качество своеобразных предправовых источников социального регулирования (как и послания Президента Федеральному Собранию, доклады Уполномоченного по правам человека) $)^{7}$.

С одной стороны, формат посланий удобен для выделения на основе анализа конституционно-судебной практики системных проблем российского законодательства и правоприменения, для устранения которых помимо изменений законодательства могут быть задействованы и конституционно-судебные средства, такие как прояснение содержания конституционных положений в процедуре официального толкования Конституции Р $\Phi^{8}$.

С другой стороны, послания могли бы играть роль обобщения судебной практики по конституционноправовым спорам и одновременно (в специальном разделе) отражать направления конституционной законодательной политики, инициативы Конституционного Суда РФ в сфере совершенствования законодательства, определять итоги реализации и проблемные зоны реализации правовых позиций и постановлений Конституционного Суда РФ.

Актуальной проблемой конституционного правосудия является определение правовой природы и структуры послания Конституционного Суда РФ, периодичность посланий и место (орган государства), в котором возможно оглашение послания Конституционного Суда РФ. По мнению Председателя Конституционного Суда РФ В.Д. Зорькина, каждое постановление Суда является мини посланием, следовательно, Суд выполняет свою миссию обращения к различным органам государства, гражданам, их объединениям. Следует поддержать данную позицию, и вместе с тем отметить, что самостоятельная роль посланий может формироваться в правовой системе России после внесения поправок в текст ФКЗ о КС, если за посланиями закрепить роль итогового документа Суда, обобщающего за определенный период (2-3 года) практику конституционного правосудия. В этом случае послания становятся инструментом влияния на эффективность исполнения (или реализации) постановлений Конституционного Суда РФ.

\footnotetext{
${ }^{7}$ Кокотов А.Н. Насущные вопросы регулирования деятельности Конституционного Суда Российской Федерации // Российский юридический журнал. 2012. № 2. С. 20 - 27.

${ }^{8}$ Там же.
}

3) Ограничения, вызванные отсутствием юридической процедуры предварительной проверки законов о поправках к Конституции на соответствие основам конституционного строя и положениям главы 2 Конституции РФ о правах и свободах человека и гражданина. В России конституционная система, опирающаяся на административные ресурсы государства, обеспечивает возможность внесения проектов Законов РФ о поправке или поправках Конституции РФ различными субъектами права на конституционную модернизацию9. Хотя перечень субъектов, имеющих право инициировать пересмотр Конституции РФ и внесения поправок в Конституцию РФ, отражает опыт и идеологию XIX-XX веков, и не соответствует современным техническим и демократическим возможностям современного государства (для этого необходимо формировать новую парадигму Конституции XXI века), рассмотрения и принятия предложений о поправках к Конституции РФ, как показывает российский опыт, имеет императивный характер только когда инициатором становится глава Российского государства. Такие поправки, как показывает российский опыт 20-летия Конституции, принимаются в юбилейные годы (в 2008 и в 2013 годах) по инициативе Президента РФ.

4) Ограничения, вызванные отсутствием полномочий у Конституционного Суда РФ обеспечивать верховенство ч.6 ст.76 Конституции РФ. Данные положения не обеспечиваются ни конституционным, ни законодательным, ни процессуальным механизмом реализации. Их нужно или устранять или обеспечивать. Конституционный контроль (в абстрактной форме) за нормативно-правовыми актами, принятыми субъектами РФ в порядке ч.6 ст.76 Конституции РФ, находится вне компетенции Конституционного Суда РФ и осуществляется другими федеральными судами или органами конституционного (уставного) контроля соответствующего субъекта Федерации. Однако органы регионального конституционного правосудия имеют ограниченные средства контроля над законодательством субъектов РФ, принятым по вопросам их собственного ведения. В случае «вторжения» федерального законодателя с помощью императивных норм в вопросы ведения субъектов РФ, конституционные (уставные) суды таких субъектов не вправе признавать федеральные законы противоречащими законам субъектов РФ, принятым в соответствии с ч.6 ст.76 Конституции РФ.

\footnotetext{
${ }^{9}$ Кравец И.А. Право на конституционную модернизацию в свете теории современного конституционализма и экономической конституции // Конституционное и муниципальное право. 2010. № 10. C. 2 - 6 .
} 
DOI: $10.7256 / 1811-9018.2013 .13 .10424$

При цитировании этой статьи сноска на dоі обязательна

Человек и государство

Представляется важным или упразднить положения ч.6 ст.76 Конституции РФ, которые в настоящее время не обеспечены надлежащим механизмом реализации («спят»), или создать действенный механизм, гарантирующий реализацию данных положений.

5) Ограничения, вызванные отсутствием обязательной процедуры проверки международных договоров, не вступивших в силу для Российской Федерации. Верховенство конституции имеет много общих черт с пониманием верховенства международного права, однако, если рассматривать соотношение норм международного права и конституции через призму свойства их взаимного верховенства, то следует признать, что такое верховенство носит взаимно ограничивающий характер. Можно предположить, что доктрина «ограниченного верховенства» наиболее подходящий концепт, который способен объяснить не только формально-юридическое, но динамическое материально-содержательное соотношение конституции как высшего и одновременно основного закона страны и норм международного права с их конституционно установленным приоритетом внутри правовой системы страны. Судебная оценка международных договоров, не вступивших в силу для Российской Федерации, применяемая в качестве обязательной процедуры могла бы стать гарантом оптимального сочетания принципа верховенства конституции и верховенства международного права. Необходимо отказаться от устоявшейся государственно-правовой традиции неучастия Конституционного Суда РФ в судебной оценке международных договоров. Введение обязательного предварительного конституционного контроля международных договоров, не вступивших в силу для Российской Федерации, позволило бы Конституционному Суду РФ формулировать правовые позиции по вопросам имплементации норм международного права и международных договоров РФ, расширило бы сферу судебной оценки международных договоров с позиций действующей Конституции РФ и стало бы важным этапом конституционализации норм международного права и международных договров.

\section{Совместимость конституционализма и сильного государства: два гаранта Конституции?}

Могут ли сосуществовать конституционализм и сильное государство одновременно в одной стране? И если это государство - Россия, как в рамках действующей конституции согласовать и обеспечить не эфемерное осуществление принципов российского конституционализма и сильного государства, ответственного за социальную и экономическую политику, способного преодолевать проблемы злоупотребления правами и противодействовать коррупции в публично-правовой сфере.

Научное осмысление реализации Конституции РФ 1993 года, которая в 2013 году отмечает 20-летие своего действия в конституционном пространстве России, происходит в условиях реального возвышения президентской власти и власти Председателя Правительства РФ. Президенстко-правительственный дуумвират федеральной государственной власти снижает роль судебных органов и особенно, конституционного правосудия в реальном обеспечении верховенства и прямого действия Конституции РФ, свидетельствует о достаточно четко формирующейся тенденции превращения российского интегрированного конституционализма в президентский конституционализм, при котором актуализация норм и положений действующей в стране Конституции во многом зависит от их понимания главой государства и от законотворческих инициатив Президента РФ и Председателя Правительства РФ. Из двух гарантов Конституции, предусмотренных её нормами (глава государства и Конституционный Суд), приоритетное положение в правовой системе и системе органов государственной власти приобретает глава государства, который благодаря определению основных направлений внешней и внутренней политики, законотворческим инициативам, арбитражной и контрольной деятельности формирует широкую социально-политическую и правовую матрицу понимания и актуализации конституционных норм и принципов в различных сегментах правовой системы страны. Конституционная политика балансирования интересов является одним из главных направлений деятельности Конституционного Суда РФ.

Конституционализм следует рассматривать как предмет конституционной политики государства. Наука конституционного права, как правило, поддерживает разграничение между правом и политикой. Поэтому термин «конституционная политика» редко встречается в российской научной литературе по конституционному праву. Однако в последние годы ряд исследователей стали рассматривать конституционную политику как разновидность правовой политики. В американской конституционной юриспруденции термин «конституционная политика» используется гораздо реже (о чем сви- 
DOI: $10.7256 / 1811-9018.2013 .13 .10424$

При цитировании этой статьи сноска на dоі обязательна

\section{Право и политика $13(168) \cdot 2013$}

детельствуют книги и статьи), чем термин «конституционное право». ${ }^{10}$

Сравнительное конституционное право основывается на методологическом плюрализме. ${ }^{11}$ В условиях интеграции России в международное и европейское правовое пространство значимость обратного влияния на российское внутригосударственное право теории и практики планетарного конституционализма необходимо рассматривать в контексте соотношения национальных особенностей и глобальных закономерностей развития и совершенствования основных принципов и институтов современного конституционализма. В международных политических исследованиях обосновывается потребность осмысления нового понимания черт и природы конституционализма, выходящего за пределы национального государства. ${ }^{12}$

\section{Возвышение конституционализма на двух столпах правовой культуры}

Роль правового регулирования в становлении и развитии конституционного государства трудно переоценить. Обязывающий характер правовых норм всегда является составной частью современного понимания конституционного государства. В различных правовых системах сформировались концепции, объясняющие роль права в регулировании общественных отношений, складывающихся в условиях конституционализма.

Англосаксонская концепция определяется понятием «верховенства права» (rule of law). В англосаксонской правовой культуре принцип верховенства права формировался постепенно, как и сама английская конституция. В общем виде верховенство права означает, что даже высшая законодательная власть не должна на законных основаниях посягать на известные основные принципы справедливости. Источник таких основных принципов справедливости был заложен в английской конституции, которая материализовалась в ряде известных исторических документов, начиная с Magna Carta 1215 года, простирающемся до Bill of Rights 1689 года, а также ан-

\footnotetext{
${ }^{10}$ Benedict, Michael Les. Constitutional Politics in the Gilded Age // Journal of the Gilded Age and the Progressive Era. January 2010. Vol. 9. N 1. P.7-8.

${ }^{11}$ Zucca, Lorenzo. Montesquieu, Methodological Pluralism and Comparative Constitutional Law // European Constitutional Law Review. 2009. Vol. 5. No 3. P. 481-500.

${ }^{12}$ Walker, Neil. Taking Constitutionalism Beyond the State // Political Studies. 2008. Vol. 56. Issue 3, p.519-543.
}

глийского общего права. ${ }^{13}$ В наиболее развитом виде эта концепция получила распространение сначала в Великобритании, США, а затем ее модификации стали применяться в других странах, которые заимствовали идеи и институты стран общего права. К таким странам в настоящее время относятся Канада, Австралия, Новая Зеландия и ряд других. Несмотря на многочисленные примеры реализации в той или иной форме концепции «верховенства права» в странах англосаксонского мира, юристы по-прежнему считают возможным рассматривать ее как идеал ${ }^{14}$.

В странах континентальной Европы возникла и действует концепция правового государства, в Германии она выражается термином Rechtsstaat, а во Франции понятием État de droit. Возникновение понятия правового государства относится к рубежу XVIII-XIX веков. Впоследствии оно развивалось и совершенствовалось, постепенно модифицировалось и его основное предназначение. В середине XIX века Роберт Моль отмечал, что государство, основанное на идее права, может осуществиться в жизни постепенно и историческим путем, путем прогрессивного развития народа из иной фазы цивилизации ${ }^{15}$. Причем для такого государства, по его мнению, нет такой формы правления, которая была бы для него обязательна вследствие внутренней необходимости или которая была бы для него единственно возможною вследствие внешних причин. Современные конституционные системы в целом подтверждают это положение. Первоначально понятие правового государства возникло как своеобразная программа ограничения государственных притязаний. В современных условиях «принцип правового государства не сводится к защите человека от государственных притязаний, а преследует двойную цель: в равной мере ограничивать и обеспечивать деятельность государства, чтобы таким образом гарантировать достоинство человека, свободу, справедливость и правовую защищенность его как в отношениях с государственной властью, так и между индивидами»» ${ }^{16}$.

\footnotetext{
${ }^{13}$ Berman, Harold J. The Struggle for Law in Post-Soviet Russia // Western Rights? Post-Communist Application. / Ed. by A. Sajo. Kluwer, 1996. - P.41-55.

${ }^{14}$ Идеал верховенства права (“the Rule-of-Law ideal”) и его различные концепции рассматривается в обширной статье Ричарда Феллона. - Fallon Richard H. "The rule of law" as a concept in constitutional discourse // Columbia Law Review. - January 1997. Vol.97. - No.1. - P.1.

${ }^{15}$ См.: Моль Р. Энциклопедия государственных наук. - СПб., 1868. - C.256.

${ }^{16}$ Шмидт-Асман Е. Правовое государство // Государственное право Германии. / Отв. ред. Б.Н. Топорнин. - М.: Институт государства
} и права, 1994. - С.54. 
DOI: $10.7256 / 1811-9018.2013 .13 .10424$

При цитировании этой статьи сноска на dоі обязательна

Человек и государство

Концепция правового государства стала ответом абсолютистскому государству, которое характеризовалось отсутствием свобод, концентрацией власти и безответственностью власти перед обществом, а юридические гарантии правового государства соответствовали требованиям современного конституционализма. По мнению Д. Валадеса, конституционализм включает в себя два базовых элемента, которые по прошествии времени стали рассматриваться как синонимы правового государства, - это верховенство конституции и разграничение функций при осуществлении власти. ${ }^{17}$

Конституционная система не может функционировать без господства права, ведь конституция наиболее высокий тип права, а конституционное регулирование - наиболее значимое для страны. Однако в каждой стране различные концепции обязывающей силы права создали характерную для данной страны систему конституционализма ${ }^{18}$.

Понимание проблемы установления пределов государственной власти существовало в теории конституционализма в XIX веке. Границы вмешательства государственной власти определялись сферой гражданского общества. С точки зрения современного конституционализма, мера усложнения общественных отношений требует от конституции установления пределов государственного вмешательства в сферу общественного саморегулирования с таким расчетом, чтобы это вмешательство не могло повредить институтам и механизмам саморегулирования ${ }^{19}$. Такой взгляд на конституционализм может быть принят, если институты и механизмы саморегулирования способствуют реализации субъективных прав и свобод человека и обеспечивают их защиту, а собственная ценность саморегулирования общества не должна преобладать над ценностями прав и свобод личности. Поэтому либеральный конституционализм необходимо переосмыслить применительно к российским условиям современного демократического развития.

Необходимо найти правовую форму согласования принципа ограниченного правления и современной преобразовательной роли государства в процессе проведения социально-политических и экономических реформ.

Существуют объективные условия пересмотра доктрины ограниченного правления либерального консти-

${ }^{17}$ Валадес Д. Конституционные проблемы правового государства / Пер. с исп. И.Н. Шумского. - М., 2009. - С.20.

${ }^{18}$ Шайо А. Самоограничение власти (краткий курс конституционализма): Пер. с венг. - М.: Юрист, 2001. - С.205.

${ }^{19}$ Там же. - C.10. туционализма применительно к современному этапу развития Российского государства. Во-первых, в России происходят одновременные преобразования политикоправовой и социально-экономической сфер жизнедеятельности общества, которые требуют активной функциональной роли государства. Во-вторых, в связи с тем, что государство выступает основным инструментом социальных преобразований, наиболее возможным и адекватно отражающим преобразовательную деятельность становится особый тип конституционализма - государственнический конституичинализм. В-третьих, изживание российских традиций авторитаризма совершается через правовую деятельность самого государства, через обретение правовых форм при осуществлении государственных функций и формирование конституционно-правовой ответственности органов государства. В этом смысле государство предпринимает ряд правовых мер по самоограничению власти.

Применительно к конституционно-правовой сфере можно говорить об использовании неолиберальных инструментов правового регулирования деятельности государства, в том числе по отношению к экономической системе. Такая государственная деятельность порождает феномен государственнического конституционализма, который имеет ряд особенностей. Такой конституционализм инициируется самим государством в ходе преобразований правовой системы страны. С помощью конституционно-правовых механизмов государственная власть проводит социально-экономические и политико-правовые реформы и одновременно создает гарантии реализации основных прав и свобод личности. В силу большой реформаторской деятельности государства необходимы дополнительные правовые механизмы ограничения государственной власти, которые находят выражение в формирующихся институтах конституционно-правовой и федеративной ответственности органов государства.

\section{Конституционно-правовые инновации в механизме защиты основных прав и свобод}

Конституционно-правовые инновации следует признать разновидностью инноваций в праве, они возникают в сфере конституционно-правового регулирования и порождают качественные изменения регулируемых общественных отношений. Природа конституционно-правовых инноваций в отечественной юриспруденции остается не исследованной, конституционная юриспруденция одна из первых в отечественном праве ставит вопрос, что следует понимать 
DOI: $10.7256 / 1811-9018.2013 .13 .10424$

При цитировании этой статьи сноска на dоі обязательна

\section{Право и политика $13(168) \cdot 2013$}

под правовыми инновациями в целом и под конституционно-правовыми инновациями в частности.

Не всякие изменения и дополнения действующего конституционного законодательства приводят к появлению конституционно-правовых инноваций. Даже когда речь идет о конституционной модернизации, предполагающей внесение поправок в Конституцию или пересмотр Конституции, не всегда можно говорить о появлении конституционно-правовых инноваций. Только новые качественные и системные преобразования в конституционно-правовой сфере могут породить инновации. В частности, на наш взгляд, разработка наукой конституционного права и отражения в актах конституционного законодательства права на конституционную модернизацию с признанием более широкого перечня субъектов такого права, включающего как органы государственной власти, их должностные лица, так и объединения граждан, применение инновационных методов учета предложений о поправках к Конституции, создание виртуального макета конституции можно рассматривать в комплексе как появление конституционно-правовых инноваций.

Деятельность Конституционного Суда РФ по распространению конституционных прав на юридические лица, а также признание коммерческих и некоммерческих организаций, органов местного самоуправления надлежащими субъектами права на конституционную жалобу за период с 1995 по 2013 годы можно с полным основанием рассматривать как судебные конституционно-правовые инновации.

Конституционно-правовые инновации, вводимые в правовую систему России Конституционным Судом РФ, особенно значимы, т.к. позволяют совершенствовать разнообразные компоненты правовой системы, и в первую очередь конститутивное основание, каркас правовой системы страны, используя судебно-конституционные процедуры, ориентированные на защиту основных прав и свобод личности, прав юридических лиц. Такие конституционно-правовые инновации являются позитивными и прогрессивными инструментами совершенствования правовой системы.

В Федеральном конституционном законе от 3 ноября 2010 года о внесении изменений и дополнений в Федеральный конституционный закон «О Конституционном Суде Российской Федерации» закреплены изменения в некоторых условиях подачи жалобы, как от отдельных граждан, так и от объединений граждан. ${ }^{20}$

${ }^{20} \mathrm{O}$ внесении изменений в Федеральный конституционный закон «О Конституционном Суде Российской Федерации»: Федеральный конституционный закон от 3 ноября 2010 г.
После вступления в силу изменений правом на обращение в Конституционный Суд РФ с индивидуальной или коллективной жалобой на нарушение конституционных прав и свобод обладают граждане, чьи права и свободы нарушаются законом, примененным в конкретном деле, и объединения граждан, а также иные органы и лица, указанные в федеральном законе. Теперь условий допустимости жалобы (ст.97 ФКЗ о КС РФ) в количественном измерении стало меньше, однако в качественном плане происшедшие изменения заслуживают названия конституционно-правовых инноваций. Однако являются ли такие конституционно-законодательные инновации позитивными и прогрессивными инструментами совершенствования правовой системы, расширения доступа граждан и их объединений к конституционному правосудию. Жалоба на нарушение законом конституционных прав и свобод допустима, если: 1) закон затрагивает конституционные права и свободы граждан; 2) закон применен в конкретном деле, рассмотрение которого завершено в суде.

Следовательно, граждане и их объединения с учетом толкования отмеченных норм формирующейся судебно-конституционной практикой вправе подавать жалобу после вынесения судебного акта по итогам рассмотрения дела судом общей юрисдикции или арбитражным судом (для «объединений граждан»). Гражданам необходимо дожидаться теперь вынесения в отношении них судебного акта той или иной судебной инстанцией. Если конкретное дело является «административным», то оно не удовлетворяет требованиям о допустимости жалобы, а в предшествующий период конкретное дело могло носить как судебный, так и административный характер. Обращаясь к понятию конституционно-правовой инновации, хочется отметить, что внесенные изменения в законодательство о конституционном правосудии в отношении условий подачи жалобы существенно ограничивают право на конституционную жалобу по сравнению с предшествующим периодом, их следует рассматривать как установленные федеральным конституционным законом ограничения конституциионного права граждан на жалобу в Конституционный Суд РФ. Однако данное ограничение не отразилось существенным образом на количественные показатели обращений граждан и их объединений в Конституционный Суд РФ. Благодаря процедуре письменного судопроизводства согласно ст.47.1 ФКЗ о КС РФ расширилась

№ 7-ФКЗ // Собрание законодательства Российской Федерации. - 2010. - № 45. - СТ. 5742. 
DOI: $10.7256 / 1811-9018.2013 .13 .10424$

При цитировании этой статьи сноска на dоі обязательна

Человек и государство

возможность Конституционного Суда РФ принимать итоговые решения в защиту основных прав и свобод граждан, прав юридических лиц без слушания дела.

В отношении запроса суда регулирование изменилось таким образом, что теперь принятие судом решения по конкретному делу создает для него непреодолимое препятствие для обращения с запросом. Однако иные судебные инстанции сохраняют право на обращение в Конституционный Суд РФ. Интересные размышления и оценка новаций в законодательство о конституционном правосудии содержатся в работах С.А. Авакьяна ${ }^{21}$, В.А. Кряжкова, М.А. Митюкова ${ }^{22}$.

Данная законодательная новация является новым прочтением конституционных положений ч.4 ст.125 Конституции РФ. Буквальный смысл ч.4 ст.125 Конституции РФ не позволяет развести условия обращения с жалобой граждан и с запросом судов в отношении проверки конституционности закона, примененного или подлежащего применению в конкретном деле.

Представляется, что может появиться значительная область конфликтов между Конституционным Судом РФ (КС РФ) и Европейским Судом по правам человека (ЕСПЧ), т.к. граждане введенным ограничением будут ориентированы на обращения в ЕСПЧ или одновременно в оба суда. Введенные новации могут способствовать возвышению национального органа конституционного правосудия в вопросах защиты основных прав и свобод личности, прав юридических лиц, если Конституционный Суд РФ будет соизмерять возможности применения устной и письменной формы конституционного судопроизводства для целей эффективной защиты основных прав и свобод, а также не только использовать правовые позиции Европейского Суда по правам человека, но и предвосхищать их возможное содержание опираясь на истолкование конституционных положений о правах и свободах в духе европейского права в области прав человека.

Постановления и заключения Конституционного Суда Российской Федерации не позднее чем в двухнедельный срок со дня их подписания направляются указанным в ФКЗ о КС (ст.77) органам и лицам. Однако действующее законодательство

\footnotetext{
${ }^{21}$ Авакьян С.A. Конституционный Суд Российской Федерации: неоднозначные законодательные новеллы / С.А. Авакьян // Конституционное и муниципальное право. -2011 . - № 1. - С.3-7.

${ }^{22}$ Кряжков В.А., Митюков М.А. Конституционный Суд Российской Федерации: развитие конституционно-правового статуса / В.А. Кряжков, М.А. Митюков // Государство и право. -2011. - № 10. - C.12-28.
}

о конституционном правосудии не устанавливает срок оглашения постановления Конституционного Суда РФ по жалобе после того, как дело было рассмотрено со слушанием. Реально такой срок оглашения может колебаться (как показывает практика Конституционного Суда РФ в период с 2011 по 2013 годы) от 25 до 53 дней с момента рассмотрения дела. Поэтому Суд вынужден специально объявлять для заинтересованных лиц (не только сторон и их представителей) точную дату оглашения постановления Конституционного Суда РФ (на официальном сайте). Для постановлений Конституционного Суда РФ, принятых по жалобе в соответствии со ст.47.1 Федерального конституционного закона «О Конституционном Суде РФ» без слушания дела, не устанавливается срок официального опубликования. Между тем такие постановления вступают в силу только после их официального опубликования.

Представляется важным внести изменения и дополнения в Федерального конституционного закона «О Конституционном Суде РФ», установив 14-дневный срок оглашения постановления Конституционного Суда РФ со дня рассмотрения дела со слушанием, и предусмотрев 14-дневный срок официального опубликования постановления Конституционного Суда РФ, принятого без слушания дела.

\section{Библиография:}

1. Limbach Jutta. The Concept of the Supremacy of the Constitution // The Modern Law Review. 2001. Vol.64. No 1. P.1.

2. Бондарь Н.С. Буква и дух российской Конституции: 20-летний опыт гармонизации в свете конституционного правосудия // Журнал российского права. 2013. № 11. С. 5-17.

3. Кельзен Г. Судебная гарантия конституции (конституционная юстиция) // Право и политика. 2006. № 8, 9 .

4. Шмитт Карл. Государство. Право и политика. М., 2013.

5. Бондарь Н.С. Судебный конституционализм в России в свете конституционного правосудия. М.: Норма; ИНФРА-М, 2011.

6. Кравец И.А. О понятии судебного конституционализма // Правовые проблемы укрепления российской государственности: Сб. ст. / Под ред. М.М. Журавлева, А.М. Барнашова, В.М. Зуева. Томск: Изд-во Том. Ун-та, 2010. Ч. 46. С. 58 - 59. 


\section{Право и политика $13(168) \cdot 2013$}

7. Ярошенко Н.И. Судебный конституционализм в Российской Федерации: понятие и система оснований // Российская юстиция. 2013. № 8. С. 4-6.

8. Митюков М.А. Методология исследования проблемы послания Конституционного Суда Российской Федерации // Конституционное и муниципальное право. 2010. № 12. С. 27 - 33.

9. Несмеянова С.Э. О возможном влиянии Конституционного Суда Российской Федерации на законодателя // Журнал конституционного правосудия. 2010. № 3. С. 6-9.

10. Кокотов А.Н. Насущные вопросы регулирования деятельности Конституционного Суда Российской Федерации // Российский юридический журнал. 2012. № 2. С. 20-27.

11. Кравец И.А. Право на конституционную модернизацию в свете теории современного конституционализма и экономической конституции // Конституционное и муниципальное право. 2010. № 10. C. 2-6.

12. Benedict, Michael Les. Constitutional Politics in the Gilded Age // Journal of the Gilded Age and the Progressive Era. January 2010. Vol. 9. N 1. P.7-8.

13. Zucca, Lorenzo. Montesquieu, Methodological Pluralism and Comparative Constitutional Law // European Constitutional Law Review. 2009. Vol. 5. No 3. P. 481-500.

14. Walker, Neil. Taking Constitutionalism Beyond the State // Political Studies. 2008. Vol. 56. Issue 3, p.519543.

15. Berman, Harold J. The Struggle for Law in PostSoviet Russia // Western Rights? Post-Communist Application. / Ed. by A. Sajo. Kluwer, 1996. P.41-55.

16. Fallon Richard H. "The rule of law" as a concept in constitutional discourse // Columbia Law Review. January 1997. Vol.97. No.1. P.1.

17. Моль Р. Энциклопедия государственных наук. СПб., 1868. С.256.

18. Шмидт-Асман Е. Правовое государство // Государственное право Германии. / Отв. ред. Б.Н. Топорнин. М.: Институт государства и права, 1994. C.54.

19. Валадес Д. Конституционные проблемы правового государства / Пер. с исп. И.Н. Шумского. М., 2009. C.20.

20. Шайо А. Самоограничение власти (краткий курс конституционализма): Пер. с венг. М.: Юрист, 2001. C.205.

21. О внесении изменений в Федеральный конституционный закон «О Конституционном Суде
Российской Федерации»: Федеральный конституционный закон от 3 ноября 2010 г. № 7-ФКЗ // Собрание законодательства Российской Федерации. 2010. № 45. Ст. 5742.

22. Авакьян С.А. Конституционный Суд Российской Федерации: неоднозначные законодательные новеллы / С.А. Авакьян // Конституционное и муниципальное право. 2011. № 1. С.3-7.

23. Кряжков В.А., Митюков М.А. Конституционный Суд Российской Федерации: развитие конституционно-правового статуса / В.А. Кряжков, М.А. Митюков // Государство и право. 2011. № 10. С.12-28.

24. Н.С. Бондарь Конституционное правосудие и развитие конституционной юриспруденции в России: теория и практика. // Журнал зарубежного законодательства и сравнительного правоведения. $-2011 .-4$. - С. 6 - 15.

\section{References (transliteration):}

1. Limbach Jutta. The Concept of the Supremacy of the Constitution // The Modern Law Review. 2001. Vol.64. No 1. P.1.

2. Bondar' N.S. Bukva i dukh rossiiskoi Konstitutsii: 20-letnii opyt garmonizatsii $\mathrm{v}$ svete konstitutsionnogo pravosudiya // Zhurnal rossiiskogo prava. 2013. № 11. S. 5-17.

3. Kel'zen G. Sudebnaya garantiya konstitutsii (konstitutsionnaya yustitsiya) // Pravo i politika. 2006. № 8, 9.

4. Shmitt Karl. Gosudarstvo. Pravo i politika. M., 2013.

5. Bondar' N.S. Sudebnyi konstitutsionalizm v Rossii v svete konstitutsionnogo pravosudiya. M.: Norma; INFRA-M, 2011.

6. Kravets I.A. O ponyatii sudebnogo konstitutsionalizma // Pravovye problemy ukrepleniya rossiiskoi gosudarstvennosti: Sb. st. / Pod red. M.M. Zhuravleva, A.M. Barnashova, V.M. Zueva. Tomsk: Izd-vo Tom. Un-ta, 2010. Ch. 46. S. $58-59$.

7. Yaroshenko N.I. Sudebnyi konstitutsionalizm v Rossiiskoi Federatsii: ponyatie i sistema osnovanii // Rossiiskaya yustitsiya. 2013. № 8. S. 4-6.

8. Mityukov M.A. Metodologiya issledovaniya problemy poslaniya Konstitutsionnogo Suda Rossiiskoi Federatsii // Konstitutsionnoe i munitsipal'noe pravo. 2010. № 12. S. 27 - 33.

9. Nesmeyanova S.E. O vozmozhnom vliyanii Konstitutsionnogo Suda Rossiiskoi Federatsii na zakonodatelya // Zhurnal konstitutsionnogo pravosudiya. 2010. № 3. S. 6-9. 
DOI: $10.7256 / 1811-9018.2013 .13 .10424$

При цитировании этой статьи сноска на dоі обязательна

Человек и государство

10. Kokotov A.N. Nasushchnye voprosy regulirovaniya deyatel'nosti Konstitutsionnogo Suda Rossiiskoi Federatsii // Rossiiskii yuridicheskii zhurnal. 2012. № 2. S. 20-27.

11. Kravets I.A. Pravo na konstitutsionnuyu modernizatsiyu v svete teorii sovremennogo konstitutsionalizma i ekonomicheskoi konstitutsii // Konstitutsionnoe i munitsipal'noe pravo. 2010. № 10. S. 2-6.

12. Benedict, Michael Les. Constitutional Politics in the Gilded Age // Journal of the Gilded Age and the Progressive Era. January 2010. Vol. 9. N 1. P.7-8.

13. Zucca, Lorenzo. Montesquieu, Methodological Pluralism and Comparative Constitutional Law // European Constitutional Law Review. 2009. Vol. 5. No 3. P. 481-500.

14. Walker, Neil. Taking Constitutionalism Beyond the State // Political Studies. 2008. Vol. 56. Issue 3, p.519-543.

15. Berman, Harold J. The Struggle for Law in Post-Soviet Russia // Western Rights? Post-Communist Application. / Ed. by A. Sajo. Kluwer, 1996. P.41-55.

16. Fallon Richard H. "The rule of law" as a concept in constitutional discourse // Columbia Law Review. January 1997. Vol.97. No.1. P.1.
17. Mol' R. Entsiklopediya gosudarstvennykh nauk. SPb., 1868. S.256.

18. Shmidt-Asman E. Pravovoe gosudarstvo // Gosudarstvennoe pravo Germanii. / Otv. red. B.N. Topornin. M.: Institut gosudarstva i prava, 1994. S.54.

19. Valades D. Konstitutsionnye problemy pravovogo gosudarstva / Per. s isp. I.N. Shumskogo. M., 2009. S.20.

20. Shaio A. Samoogranichenie vlasti (kratkii kurs konstitutsionalizma): Per. s veng. M.: Yurist, 2001. S.205.

21. Avak'yan S.A. Konstitutsionnyi Sud Rossiiskoi Federatsii: neodnoznachnye zakonodatel'nye novelly / S.A. Avak'yan // Konstitutsionnoe i munitsipal'noe pravo. 2011. № 1. S.3-7.

22. Kryazhkov V.A., Mityukov M.A. Konstitutsionnyi Sud Rossiiskoi Federatsii: razvitie konstitutsionnopravovogo statusa / V.A. Kryazhkov, M.A. Mityukov // Gosudarstvo i pravo. 2011. № 10. S.12-28.

23. N.S. Bondar' Konstitutsionnoe pravosudie i razvitie konstitutsionnoi yurisprudentsii v Rossii: teoriya $\mathrm{i}$ praktika. // Zhurnal zarubezhnogo zakonodatel'stva i sravnitel'nogo pravovedeniya. - 2011. - 4. - C. 6-15. 